\title{
Structure and trophic organization of subtidal fish assemblages on the northern Chilean coast: the effect of habitat complexity
}

\author{
Andrea Angel, F. Patricio Ojeda* \\ Departamento de Ecología, Facultad de Ciencias Biológicas, P. Universidad Católica de Chile, Casilla 114-D, Santiago, Chile
}

\begin{abstract}
A series of local factors such as substrate structure, presence or absence of kelp forests and environmental variables play an important role in determining both the diversity and abundance of temperate reef fish assemblages. The presence of kelp forests has been shown to increase structural complexity, available shelter, and prey availability in the reef environment. This, in turn, may affect the structural organization of the fish assemblage. In this study, the diversity, abundance and trophic patterns of subtidal fish assemblages at 2 localities off the northern Chilean coast were analyzed. These localities differ markedly in their spatial structure: the subtidal substratum at Caleta Errázuriz is characterized by a sloping bedrock with large rocks and boulders and a kelp forest, while at Carrizal Bajo it consists of a sharply declining bedrock with few boulders and isolated kelp stands. We hypothesized that structurally highly complex habitats would exhibit higher diversity, abundance and a more complex trophic organization in terms of more functional groups and guilds of reef fish assemblages than less structured environments. Contrary to our hypothesis, we found similar species diversity and fish abundance at both localities. However, there were clear differences in species dominance, number of functional groups and trophic guilds. There were also marked differences in the trophic webs between localities. In the presence of kelp forest, both carnivores and omnivores consumed mainly benthic prey inhabiting the understory canopy, while in its absence carnivores fed on pelagic prey in the water column. Therefore, a more complex spatial structure would seem to support a more complex trophic organization with a greater degree of connectivity, as well as interaction between the species in a reef fish assemblage.
\end{abstract}

KEY WORDS: Temperate reef fish $\cdot$ Habitat complexity $\cdot$ Kelp forests $\cdot$ Trophic guilds $\cdot$ Functional groups

\section{INTRODUCTION}

The complexity of habitat structure has been largely recognized as one of the factors affecting the diversity, distribution and abundance of rocky reef fishes (Quast 1968, Ebeling et al. 1980). A series of studies conducted along temperate shallow-reef environments have shown that the abundance and composition of subtidal fish assemblages are strongly determined by factors that express themselves on a local scale, such as

${ }^{*}$ Corresponding author. E-mail: pojeda@genes.bio.puc.cl substrate structure (Ebeling et al. 1980, Steele 1999), physical environmental variables (Dayton 1985, Tegner \& Dayton 1987, Ebeling \& Hixon 1991) and the presence or absence of kelp forests (Bodkin 1988, Levin \& Hay 1996). Steele (1999) found increasing recruitment and survival of reef fishes to be influenced by the availability of potential shelter sites, which served as refuge from predation, and by prey preferences. Likewise, Ebeling et al. (1980) found that more complex rock-reef surfaces harbour a greater diversity and abundance of reef fishes. In general terms, and depending on the composition and abundance of grazing invertebrates such as echinoids or small crusta- 
ceans, areas dominated by rocky substratum will present encrusting and turfing red algal associations or dense kelp populations (Choat \& Schiel 1982, Schiel \& Foster 1986). Such distinct algal assemblages will have a major influence on the associated fish fauna (Choat \& Ayling 1987). Wharton \& Mann (1981) argue that kelp stands provide shelter and structural complexity in reef environments, resulting in increased abundance and diversity of organisms such as fishes and larger crustaceans. Despite the recognition in a large number of studies of the relationship between the presence of kelp forests and increased abundance and diversity of temperate reef fishes (Bodkin 1988, DeMartini \& Roberts 1990, Holbrook et al. 1990, Carr 1991, Anderson 1994: but see exceptions documented in the studies of Stephens et al. [1984] and Choat \& Ayling [1987]), much less attention has been paid to discovering how these structurally complex environments may affect the trophic organization of the associated fish assemblages (Love \& Ebeling 1978).

Along the coast of Chile, the shallow-reef environments are dominated by a large suite of fish species, with wide geographical ranges (Miranda 1967, Nuñez \& Vasquez 1987, Vargas et al. 1999). Moreno et al. (1979) compared subtidal communities at 2 localities, one on the central Chilean coast and the other further south. They observed greater community diversity in the central zone and proposed that these latitudinal variations were due to a more complex environmental matrix arising from the presence of kelp forests at lower latitudes. This increased complexity would allow greater species packing and thus explain the enhanced fish diversity. More recently, Moreno \& Jara (1984) in their analysis of the kelp-fish community rela-

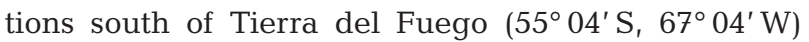
argued that both species abundance and diversity of kelp fish assemblages depend almost exclusively on bottom relief. Increased bottom heterogeneity allows for more refuge and accumulations of drift algae, which is cycled and made available to the fish assemblages through detritivorous crustaceans (Moreno \& Jara 1984). From these studies it becomes clear that areas dominated by rocky substratum and kelp forests provide more opportunities not only for habitat utilization by reef fishes (e.g., shelter), but also for the prey species on which they feed.

In order to analyze the influence of habitat complexity on the structure and trophic organization of subtidal fish assemblages, we studied their diversity, abundance and trophic patterns at 2 localities on the northern Chilean coast, which differ markedly in spatial structure. The trophic organization of these fish assemblages was studied using a trophic functional approach as well as by identifying their trophic guild structure (Muñoz \& Ojeda 1997).
We hypothesized that a structurally highly complex habitat, such as Caleta Errázuriz, would exhibit higher diversity, abundance and a more complex trophic organization in terms of more functional groups and guilds of reef fish assemblages than the less structured environments, such of Carrizal Bajo.

\section{MATERIALS AND METHODS}

Study sites. This study was carried out at 2 localities on the northern Chilean coast, Caleta Errázuriz $\left(23^{\circ}\right.$ $\left.24^{\prime} \mathrm{S}, 70^{\circ} 35^{\prime} \mathrm{W}\right)$ and Carrizal Bajo $\left(28^{\circ} 04^{\prime} \mathrm{S}, 70^{\circ} 35^{\prime} \mathrm{W}\right.$ : Fig. 1), hereafter referred to as $\mathrm{CE}$ and $\mathrm{CB}$, respectively. The subtidal substratum at both localities was characterized by conducting visual unterwater transect along $200 \mathrm{~m}$ of shore and $150 \mathrm{~m}$ offshore. CE is an area of high bottom-relief, its subtidal substratum being characterized by a sloping bedrock with large rocks and boulders that extend from 0 to $8 \mathrm{~m}$ depth and occupy 75 to $85 \%$ of the surveyed area. This habitat alternates with patches of sand in the deeper fringes (8 to $10 \mathrm{~m}$ depth) making up the remaining 25 to $15 \%$ of the habitat. At this site, large plants of the brown kelp species Lessonia trabeculata and Macrocystis integrifolia form extensive kelp forests (Camus \& Ojeda 1992, Cáceres et al. 1994). In contrast, CB is as area of low bottom-relief: the subtidal substratum consists of a sharply declining bedrock with few boulders

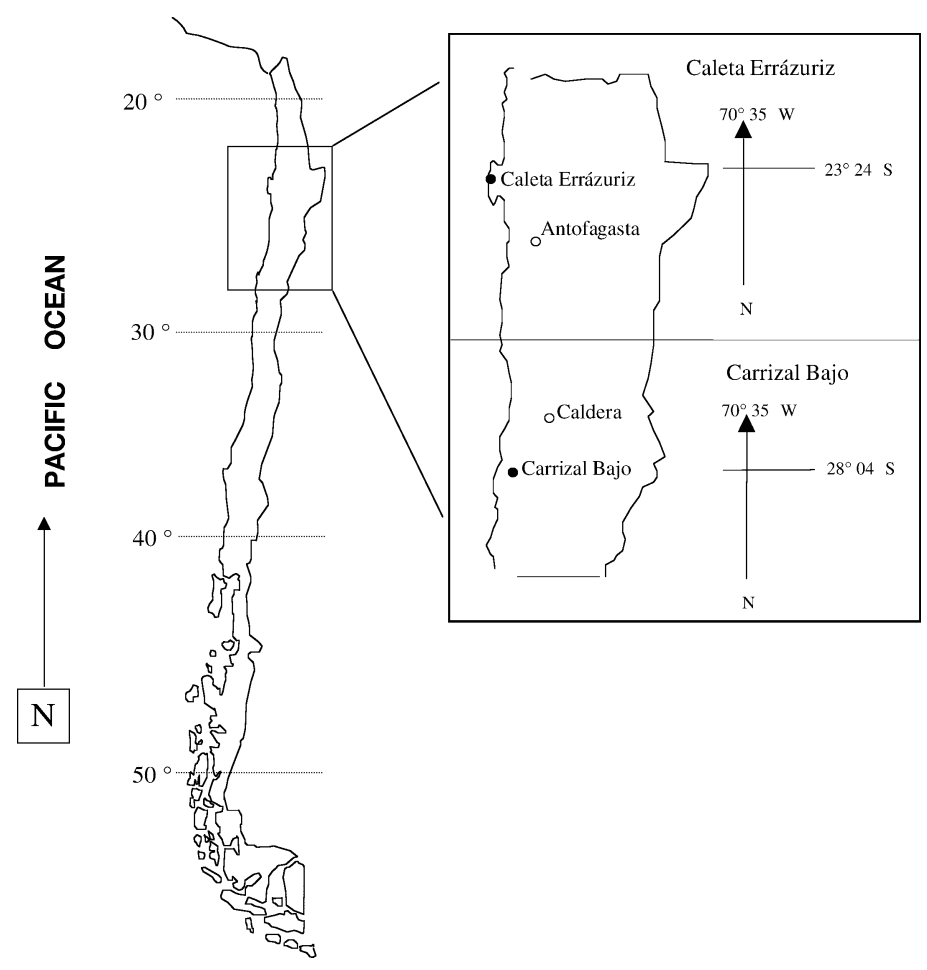

Fig. 1. Location of study sites on northern Chilean coast 
( 0 to $7 \mathrm{~m}$ depth) that cover 30 to $45 \%$ of the surveyed area; the remaining habitat consisting of a sandy bottom with scattered rocks in the deeper fringes at the area ( 7 to $12 \mathrm{~m}$ depth). There are no kelp forests at this locality, only scattered $L$. trabeculata stands. Both sites correspond to exposed coastal areas with predominant south-west winds and upwelling pulses, which are slightly stronger at CE (Vásquez et al. 1998). Mean sea surface temperatures increased towards December 1997 due to the El Niño episode of 1997/1998, with productivity values (chlorophyll conc.) below $2 \mu \mathrm{g} \mathrm{l^{-1 }}$ during the whole study period at both sites. Thus, the habitat-type characteristics kelp density and bottom relief would seem to be the main factors differentiating both sites (Jaramillo et al. 1998).

Sampling. Fishes were seasonally (quarterly) sampled at each locality from July 1996 to November 1997 using three $3 \mathrm{~m}$ high $\times 40 \mathrm{~m}$ long experimental gillnets consisting of 6 panels (graded in mesh size from 10 to $70 \mathrm{~mm}$ ) that were randomly set in parallel on the bottom, perpendicular to the shore, at depths between 5 and $15 \mathrm{~m}$. The variable mesh size of these nets reduces selective capture of fishes and optimizes the capture of small-sized fishes. Visual counts were also carried out in order to complement the use of gillnets. However, because of low visibility (maximum 5 to $6 \mathrm{~m}$ ), the diversity and abundance recorded was lower than those obtained with the nets, although the proportion of the most abundant fish was the same with both methods at both localities (unpubl. data). On each sampling date, the nets were deployed on $3 \mathrm{~d}$ (between dawn and dusk) and 3 nights (between dusk and dawn). At dawn and dusk each day, the nets were collected and all specimens removed. Captured specimens were fixed in a $10 \%$ solution of buffered formalin-seawater mixture, placed in labelled plastic bags, and transported to the laboratory for further analysis. The abundance patterns of the total number of captured species was determined by a catch-per-unit-effort (CPUE) index corresponding to the total number of captured individuals of each species divided by the total number of sampling hours during each season at each locality. In the laboratory, the fishes were identified to species level, total length (TL) measured to the nearest millimetre, and wet-weighed to the nearest $0.01 \mathrm{~g}$. Stomachs, intestines and gonads were removed. Prey items from each stomach and intestine were identified to the most exact taxonomic level possible, damp-dried on a paper towel, and weighed to the nearest $0.01 \mathrm{~g}$. Dietary composition was expressed as the percentage of total food weight pooled over all individuals for each fish species. The minimum sample size necessary to determine trophic diversity of each species was assessed using cumulative trophic diversity plots (Colwell 1997). In all cases, adequate sample size was between 10 and 30 individuals, and only those species with a sufficient number of sampled specimens were considered for the trophic analyses. To avoid possible size effects due to ontogenetic trophic shifts, only adult individuals of each species were analyzed. In species for which a sufficient number of specimens was collected, seasonal differences in dietary composition was tested using the non-parametric Kendall coefficient of concordance $(W)$ (Siegel \& Castellan 1988). As no significant differences in seasonal trophic composition were found, the diets of all species within each locality were pooled.

In accordance with the percentage biomass of animal or algae consumed, each species was classified as belonging to one of the following functional groups: herbivore, omnivore or carnivore. Species were classified as herbivores if their algal consumption was $\geq 80 \%$ of the total biomass amount consumed, as omnivores if consumption of algae was $\geq 20 \%$ and $<80 \%$, and as carnivores if the consumption of algae was $\leq 20 \%$. The degree of concordance in the dietary composition of the species sampled at each locality was evaluated using the non-parametric Kendall correlation coefficient $(\tau)$ (Siegel \& Castellan 1988).

Dietary overlap between all species pairs was calculated based on the percentage gravimetric data of each prey item, which allows comparisons among herbivores, omnivores and carnivores. Pianka's (1973) niche overlap index was used; its values range between 0 and 1 , ranging from null to complete similarity in prey use by any 2 species.

In order to determine the presence of guilds, at each locality, the methods of Muñoz \& Ojeda (1997) were used. Dietary similarity matrices were subjected to an UPGMA (unweighted pair-group method using arithmetic averages) clustering procedure (Jaksic \& Medel 1990), generating 2 dietary similarity phenograms (1 for each locality). To determine the level of dietary similarity at which guild membership could objectively be recognized, we constructed a frequency distribution of overlap values that were randomly generated by a bootstrapping procedure, and we used this frequency distribution as a basis against which the observed overlap values were compared. We used the bootstrap method proposed by Jaksic \& Medel (1990). This involves the construction of a frequency distribution of the overlap values, generated by 1000 times random reshuffling of the dietary matrix data. In order to retain the maximum structure of the original dietary matrix structure, an RA4 randomization algorithm was used (Lawlor 1980). Here, zero values are retained in their original positions and only the remaining values are reassigned randomly within columns, thus respecting the selectivity of the consumers and retaining the original food-niche breadths. The generated frequency 
distribution was compared with the observed overlap similarity values, and those that exceeded $95 \%$ were considered to be above that expected by chance. At $\mathrm{CE}$, the analysis indicated that a dietary similarity $>81 \%$ was significant, with a probability value of $<5 \%$ (1-tailed test). At CB, a dietary similarity level of $60 \%$ was significant, with a probability value of $<5 \%$.

The total number of prey species found at each locality were grouped into taxonomic prey categories in order to simplify the trophical composition of the fish species. The most important prey categories were further classified as pelagic or benthic based on the life history of the respective species. The pelagic prey categories corresponded to: copepods of the order Calanoida and the free-living species of the genus Calanus sp.; mysidaceans of the order Mysidacea and planktonic species of the genus Mysis sp.; planktonic crustacean larvae; ostracods of the order Ostracoda and planktonic species of the genus Conchoecia sp. The benthic prey cate- gories corresponded to: Chlorophyta, Rhodophyta and Phaeophyta; Porifera; amphipods of the family Gammaridea and Caprellidea; isopods of the family Idotheidae; gastropods of the genera Eationella, Colicella and Rissonia, and the various algae species grouped as red, green and brown algae.

\section{RESULTS}

\section{Relative abundance and diversity}

A total of 22 species were captured at CE and 28 at $\mathrm{CB}, 16$ of these species were common to both localities, with 6 being exclusively found at $\mathrm{CE}$ and 12 exclusively at $\mathrm{CB}$ (Table 1). Of the 12 species not found in $\mathrm{CE}, 6$ were pelagic species (Scomberomolus maculatus, Mentichirrus ophicephalus, Sciaena fasciata, Mustelus whitneyi, Schroederichthys chilensis and Callorhin-

Table 1. Fish species collected at each locality, number of individuals analyzed (N), percent of total fish captured (\%), average size $(X \pm \mathrm{SD})$ and total length (TL) range of each species. -: species absent

\begin{tabular}{|c|c|c|c|c|c|c|c|c|}
\hline \multirow{2}{*}{ Species } & \multirow[b]{2}{*}{$\mathrm{N}$} & \multirow{2}{*}{ - } & \multirow{2}{*}{$\begin{array}{c}\text { Caleta Errázuriz } \\
\qquad(X \pm \mathrm{SD})\end{array}$} & \multirow[b]{2}{*}{ TL (cm) } & \multirow[b]{2}{*}{$\mathrm{N}$} & \multirow[b]{2}{*}{$\%$} & \multirow{2}{*}{$\begin{array}{c}\text { Carrizal Bajo } \\
\qquad(X \pm \mathrm{SD})\end{array}$} & \multirow[b]{2}{*}{$\mathrm{TL}(\mathrm{cm})$} \\
\hline & & & & & & & & \\
\hline Isacia conceptionis & 126 & 17.24 & $22.1( \pm 4.1)$ & $11.5-30.0$ & 169 & 41.52 & $21.9( \pm 3.8)$ & $12.5-31.0$ \\
\hline Anisotremus scapularis & 119 & 16.28 & $22.7( \pm 3.4)$ & $11.1-32.0$ & 2 & 0.49 & $25.3( \pm 5.2)$ & $21.6-29.0$ \\
\hline Cheilodactylus variegatus & 118 & 16.14 & $24.8( \pm 4.4)$ & $10.0-35.0$ & 2 & 0.49 & $26.7( \pm 12.5)$ & $17.8-35.5$ \\
\hline Trachurus murphyi & 27 & 3.69 & $31.8( \pm 5.1)$ & $11.0-37.0$ & 111 & 27.27 & $33.7( \pm 3.1)$ & $26.0-44.5$ \\
\hline Paralabrax humeralis & 100 & 13.68 & $26.5( \pm 8.1)$ & $12.2-53.3$ & 26 & 6.39 & $34.0( \pm 8.3)$ & $10.0-50.5$ \\
\hline Mugil cephalus & 46 & 6.29 & $33.8( \pm 3.0)$ & $29.0-42.0$ & - & - & - & - \\
\hline Girella laevifrons & 46 & 6.29 & $25.2( \pm 2.4)$ & $19.9-32.0$ & 2 & 0.49 & $34.5( \pm 2.1)$ & $33.0-36.0$ \\
\hline Hemilutjanus macrophthalmos & 46 & 6.29 & $14.9( \pm 3.0)$ & $10.0-20.4$ & 5 & 1.23 & $22.7( \pm 5.1)$ & $17.0-28.3$ \\
\hline Chromis crusma & 24 & 3.28 & $12.6( \pm 3.0)$ & $9.0-19.5$ & 12 & 2.95 & $15.3( \pm 1.9)$ & $11.5-18.0$ \\
\hline Aplodactylus punctatus & 22 & 3.01 & $33.4( \pm 5.8)$ & $22.2-41.5$ & 12 & 2.95 & $29.3( \pm 4.0)$ & $24.0-37.5$ \\
\hline Nexilosus latifrons & 18 & 2.46 & $25.0( \pm 4.0)$ & $17.5-31.0$ & - & - & - & - \\
\hline Thyrsites atun & 2 & 0.27 & $39.5( \pm 3.5)$ & $37.0-42.0$ & 15 & 3.69 & $43.6( \pm 13.1)$ & $27.8-85.0$ \\
\hline Labrisomus philippi & 14 & 1.92 & $25.6( \pm 2.8)$ & $18.0-29.6$ & 1 & 0.25 & - & 34.5 \\
\hline Prolatilus jugularis & - & - & - & - & 10 & 2.46 & $30.0( \pm 2.3)$ & $26.5-34.7$ \\
\hline Stellifer minor & 3 & 0.41 & $32.0( \pm 1.4)$ & $31.0-33.0$ & 10 & 2.46 & $27.9( \pm 6.2)$ & $12.8-34.6$ \\
\hline Auchenionchus microcirrhis & 9 & 1.23 & $18.7( \pm 4.6)$ & $15.5-27.5$ & 1 & 0.25 & - & 34.0 \\
\hline Cilus gilberti & 1 & 0.14 & - & 39.0 & 6 & 1.47 & $33.9( \pm 6.7)$ & $26.5-44.0$ \\
\hline Sardinops sagax & 1 & 0.14 & $16.5( \pm 1.9)$ & $14.0-18.0$ & - & - & - & - \\
\hline Pinguipes chilensis & 1 & 0.14 & - & 20.8 & 4 & 0.98 & $35.3( \pm 6.9)$ & $29.8-45.0$ \\
\hline Scartichthys viridis & 3 & 0.41 & $15.2( \pm 0.2)$ & $15.0-15.5$ & - & - & - & - \\
\hline Scomberomorus maculattus & - & - & - & - & 3 & 0.74 & $28.3( \pm 6.5)$ & $22.0-35.5$ \\
\hline Mentichirrus ophicephalus & - & - & - & - & 2 & 0.49 & $32.2( \pm 2.5)$ & $30.4-34.0$ \\
\hline Acanthistius pictus & 2 & 0.27 & $31.5( \pm 11.3)$ & $23.5-39.5$ & - & - & - & - \\
\hline Aphos porosus & - & - & - & - & 2 & 0.49 & $20.3( \pm 3.3)$ & $18.0-22.6$ \\
\hline Paralichthys microps & - & - & - & - & 2 & 0.49 & $30.4( \pm 6.9)$ & $25.5-35.2$ \\
\hline Schroederichthys chilensis & - & - & - & - & 2 & 0.49 & $35.4( \pm 0.8)$ & $34.8-36.0$ \\
\hline Sciaena fasciata & - & - & - & - & 2 & 0.49 & $26.1( \pm 3.4)$ & $22.5-30.6$ \\
\hline Callorhinchus callorhynchus & - & - & - & - & 1 & 0.25 & - & 50.5 \\
\hline Scartichthys gigas & 2 & 0.27 & $19.6( \pm 6.2)$ & $15.2-24.0$ & 1 & 0.25 & - & 25.0 \\
\hline Seriolella violacea & 1 & 0.14 & - & 58.0 & - & - & - & - \\
\hline Hippoglossina macrops & - & - & - & - & 1 & 0.25 & - & 33.5 \\
\hline Myxodes viridis & - & - & - & - & 1 & 0.25 & - & 22.0 \\
\hline Mustelus whitneyi & - & - & - & - & 1 & 0.25 & - & 51.9 \\
\hline Sebastes capensis & - & - & - & - & 1 & 0.25 & - & 31.0 \\
\hline Total & 731 & & & & 407 & & & \\
\hline
\end{tabular}


chus callorhynchus), 2 were flatfish species common to soft-bottom substrates (Paralichthys microps and Hippoglossina macrops), and the remaining 4 species were demersal species typical of rocky reefs (Aphos porosus, Myxodes viridis, Sebastes capensis and Prolatilus jugularis). Of the 6 species not found at $\mathrm{CB}, 2$ were pelagic (Seriolella violacea and Sardinops sagax), 3 were demersal species common to kelp forests (Nexilosus latifrons, Scartichthys viridis and Acanthistius pictus), and 1 was a cosmopolitan species (Mugil cephalus). At CE, a total of 731 individuals were captured over $373 \mathrm{~h}$ on 6 sampling dates, with a total catch per unit effort (CPUE) of $2.0 \mathrm{ind}$. $\mathrm{h}^{-1} \mathrm{~A}$ total of 407 individuals were captured at $\mathrm{CB}$ over $261 \mathrm{~h}$ on 5 sample dates (July 1997 was not sampled because the locality could not be sampled due to a severe storm) with a total CPUE of 1.6 ind. $\mathrm{h}^{-1}$.

No significant differences were found between the total CPUE of the species in any one locality $\left(t_{0.05,1}=\right.$ 0.93, $\mathrm{p}=0.376)$. However, the relative dominance of fish species differed between the 2 localities. At $\mathrm{CE}$, the fish assemblage was dominated by 4 species that together represented $>60 \%$ of the total number of fishes collected. At CB, only 2 fish species represented $>70 \%$ of the total number of fishes captured (Fig. 2).
In terms of CPUE, Isacia conceptionis was the most abundant fish species at both localities. However, its relative abundance was greater at CB (41\% of the total number of fish individuals collected) than at CE $(17 \%)$ (Fig. 2).

\section{Dietary composition}

Of all fish species collected at CE, 12 were dominant in the shallow rocky subtidal (Isacia conceptionis, Anisotremus scapularis, Cheilodactylus variegatus, Trachurus murphyi, Paralabrax humeralis, Mugil cephalus, Girella laevifrons, Hemilutjanus macrophthalmos, Chromis crusma, Aplodactylus punctatus, Nexilosus latifrons and Labrisomus philippi), and together represented $>96 \%$ of the total number of fishes collected at this locality (Table 1). These species were trophically analyzed, with the exception of $M$. cephalus, which was excluded from the dietary analysis because its detritivorous feeding habits did not permit identification of dietary items. The dietary composition of the remaining 11 species was composed of a total of 76 prey items, which were grouped into 24 prey categories (Table 2). At $\mathrm{CB}$, of the 8 species collected, 7

Table 2. Dietary composition of 11 dominant fish species inhabiting the shallow rocky subtidal habitat of Caleta Errázuriz. Prey item categories are expressed as percentage frequency of total food weight for each species. As: Anisotremus scapularis; Ap: Aplodactylus punctatus; Gl: Girella laevifrons; Nl: Nexilosus latifrons; IC: Isacia conceptionis; Cv: Cheilodactylus variegatus; Ph: Paralabrax humeralis; Lp: Labrisomus philippi; Tm: Trachurus murphyi; Hm: Hemilutjanus macrophthalmos; Cc: Chromis crusma; C: carnivore; H: herbivore; O: omnivore. N: number of guts trophically analyzed

\begin{tabular}{|c|c|c|c|c|c|c|c|c|c|c|c|}
\hline Prey category & $\begin{array}{c}A s \\
(\mathrm{~N}=52)\end{array}$ & $\begin{array}{c}A p \\
(\mathrm{~N}=10)\end{array}$ & $\begin{array}{c}G l \\
(\mathrm{~N}=10)\end{array}$ & $\begin{array}{c}N l \\
(\mathrm{~N}=10)\end{array}$ & $\begin{array}{c}I C \\
(\mathrm{~N}=54)\end{array}$ & $\begin{array}{c}C V \\
(\mathrm{~N}=47)\end{array}$ & $\begin{array}{c}P h \\
(\mathrm{~N}=42)\end{array}$ & $\begin{array}{c}L p \\
(\mathrm{~N}=13)\end{array}$ & $\begin{array}{c}T m \\
(\mathrm{~N}=21)\end{array}$ & $\begin{array}{c}H m \\
(\mathrm{~N}=24)\end{array}$ & $\begin{array}{c}C C \\
(\mathrm{~N}=24)\end{array}$ \\
\hline Chlorophyta & 54.50 & 56.86 & 73.50 & 93.01 & 36.42 & 0.45 & 0.09 & 0.43 & 0.36 & 0.02 & 0.20 \\
\hline Rhodophyta & 0.91 & 36.59 & - & 1.04 & 0.07 & 1.87 & 0.04 & 0.72 & 0.08 & - & 3.27 \\
\hline Phaeophyta & 5.46 & 6.30 & 24.51 & 0.79 & 1.05 & 2.14 & 0.03 & - & - & - & - \\
\hline Unidentified algae & - & - & 1.48 & - & 1.75 & - & 0.01 & 0.42 & - & - & - \\
\hline Polychaetes & - & - & - & - & 0.29 & 0.25 & 0.06 & - & 2.52 & - & - \\
\hline Gastropods & 0.61 & 0.02 & - & - & - & 0.48 & - & 2.82 & - & - & - \\
\hline Bivalves & 12.96 & - & - & - & - & 0.34 & - & - & - & - & - \\
\hline Unidentified mollusks & - & - & - & - & - & - & 0.46 & - & - & - & - \\
\hline Planktonic larvae & 0.42 & - & - & - & 0.57 & 0.46 & 0.01 & - & 0.23 & 0.24 & 14.39 \\
\hline Ostracods & 0.68 & - & - & 0.01 & 0.01 & 0.71 & 0.07 & - & 0.01 & 0.00 & - \\
\hline Mysidaceans & 1.24 & - & - & - & 0.36 & 0.44 & 2.43 & - & 5.23 & 22.81 & - \\
\hline Stomatopods & 0.89 & - & - & - & 46.61 & - & 0.79 & - & 82.74 & 15.33 & - \\
\hline Tanaidaceans & 0.01 & - & - & - & 0.13 & 0.98 & - & - & - & - & - \\
\hline Isopods & 1.78 & - & 0.05 & - & 0.26 & 6.48 & 0.12 & - & 0.12 & 0.25 & - \\
\hline Amphipods & 14.54 & 0.23 & 0.47 & 2.32 & 3.08 & 58.02 & 0.09 & 1.60 & 0.17 & 4.00 & 2.98 \\
\hline Copepods & - & - & - & - & 1.04 & 0.25 & - & - & - & - & 79.16 \\
\hline Cumaceans & 0.40 & - & - & - & - & - & - & - & 0.02 & 0.05 & - \\
\hline Unidentified crustaceans & - & - & - & - & 3.19 & - & 13.92 & 4.16 & - & 0.07 & - \\
\hline Crabs & 4.73 & - & - & 2.83 & - & 17.40 & 60.85 & 74.23 & - & - & - \\
\hline Shrimps & 0.87 & - & - & - & 5.16 & 3.60 & 5.15 & 15.50 & 0.91 & 54.12 & - \\
\hline Unidentified decapods & - & - & - & - & - & - & 7.85 & 0.11 & 0.01 & - & - \\
\hline Sipunculans & - & - & - & - & - & - & 6.79 & - & - & - & - \\
\hline Urochordates & - & - & - & - & - & 6.12 & - & - & - & - & - \\
\hline Teleosts & - & - & - & - & - & - & 1.24 & - & 7.62 & 3.10 & - \\
\hline Trophic category & $\mathrm{O}$ & $\mathrm{H}$ & $\mathrm{H}$ & $\mathrm{H}$ & $\mathrm{O}$ & $\mathrm{C}$ & $\mathrm{C}$ & $\mathrm{C}$ & $\mathrm{C}$ & $\mathrm{C}$ & $\mathrm{C}$ \\
\hline
\end{tabular}




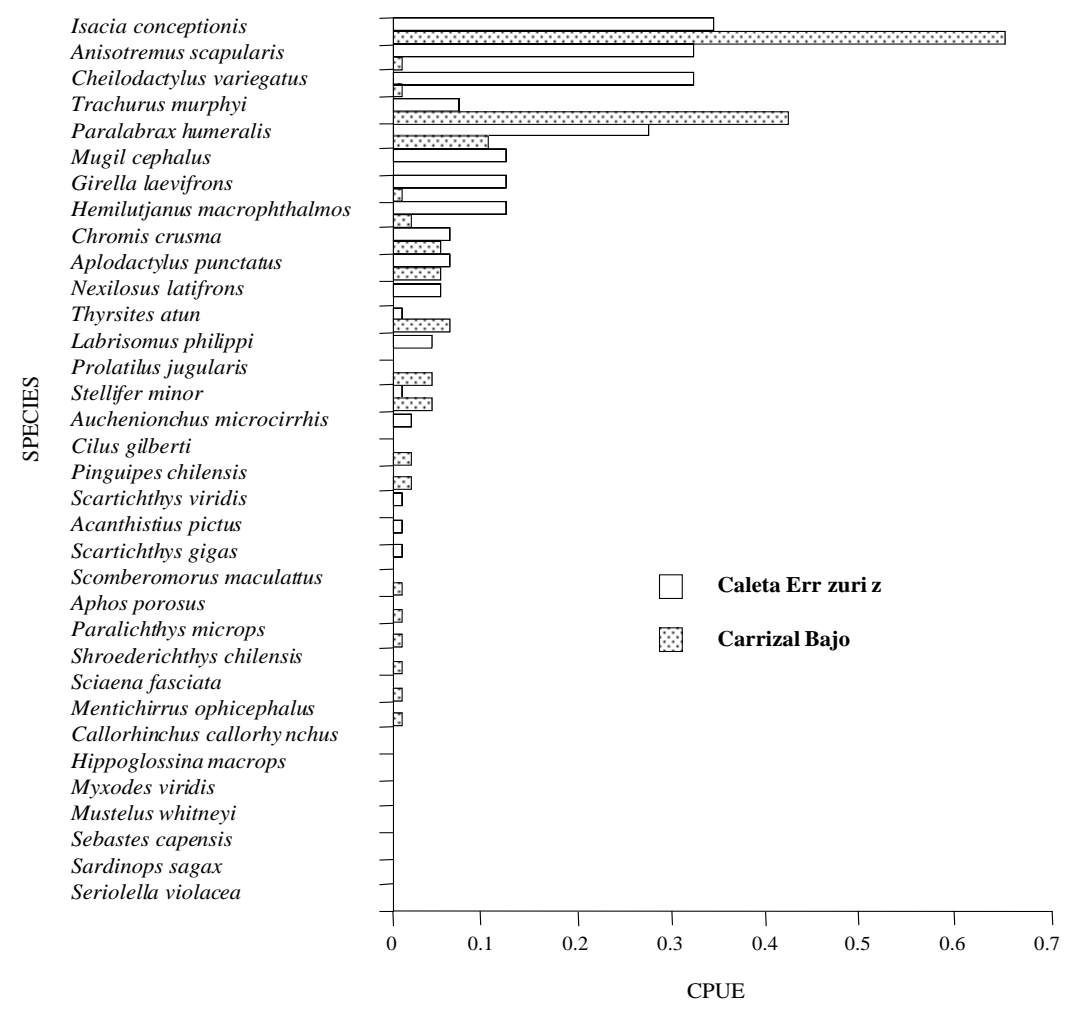

Table 3. Dietary composition of 6 dominant species inhabiting the shallow subtidal habitat of Carrizal Bajo. Prey item categories are expressed as percentage frequency of total food weight for each species. Ap: Aplodactylus punctatus; IC: Isacia conceptionis; Ph: Paralabrax humeralis; Tm: Trachurus murphyi; CC: Chromis crusma; Ta: Thyrsites atun; C: carnivore; H: herbivore. N: number of guts trophically analyzed

\begin{tabular}{|c|c|c|c|c|c|c|}
\hline Prey category & $\begin{array}{c}A p \\
(\mathrm{~N}=10)\end{array}$ & $\begin{array}{c}\text { IC } \\
(\mathrm{N}=44)\end{array}$ & $\begin{array}{c}P h \\
(\mathrm{~N}=13)\end{array}$ & $\begin{array}{c}T m \\
(\mathrm{~N}=35)\end{array}$ & $\begin{array}{c}C C \\
(\mathrm{~N}=11)\end{array}$ & $\begin{array}{c}T a \\
(\mathrm{~N}=12)\end{array}$ \\
\hline Porifera & 2.33 & - & - & - & - & - \\
\hline Chlorophyta & 4.60 & 4.81 & 0.01 & 0.01 & - & - \\
\hline Rhodophyta & 6.73 & 0.54 & 0.09 & - & - & - \\
\hline Phaeophyta & 84.17 & 1.63 & 1.39 & 0.02 & - & - \\
\hline Unidentified algae & 1.47 & 0.09 & 0.06 & - & 0.19 & - \\
\hline Polychaetes & - & 0.02 & - & - & - & - \\
\hline Gastropods & 0.08 & - & - & - & 9.21 & - \\
\hline Bivalves & 0.02 & 0.06 & 0.66 & - & - & - \\
\hline Planktonic larvae & - & 42.78 & 0.01 & 6.57 & - & - \\
\hline Ostracods & - & 0.57 & - & - & 75.54 & - \\
\hline Mysidaceans & - & 0.26 & 6.55 & 8.04 & - & - \\
\hline Stomatopods & - & - & 0.62 & - & - & - \\
\hline Tanaidaceans & - & 0.38 & - & - & - & - \\
\hline Isopods & - & 2.41 & 2.90 & 1.27 & - & - \\
\hline Amphipods & 0.02 & 23.81 & - & 0.06 & - & - \\
\hline Copepods & - & 8.04 & - & 0.07 & 15.07 & - \\
\hline Cumaceans & - & 11.93 & 0.14 & - & - & - \\
\hline Unidentified crustacear & ans- & 2.38 & 3.76 & 1.28 & - & - \\
\hline Crabs & - & - & 38.69 & - & - & - \\
\hline Shrimps & - & - & 2.99 & - & - & - \\
\hline Unidentified decapods & s - & 0.28 & 10.11 & - & - & - \\
\hline Urochordates & 0.58 & - & - & - & - & - \\
\hline Teleosts & - & 0.01 & 32.01 & 82.67 & - & 100.00 \\
\hline Trophic category & $\mathrm{H}$ & $\mathrm{C}$ & $\mathrm{C}$ & $\mathrm{C}$ & $\mathrm{C}$ & $\mathrm{C}$ \\
\hline
\end{tabular}

Fig. 2. Relative abundance in terms of catch-per-unit-effort (CPUE) of all species captured in the subtidal zones at Caleta Errázuriz and Carrizal Bajo

were dominant in the shallow rocky subtidal zone (Isacia conceptionis, Trachurus murphyi, Paralabrax humeralis, Chromis crusma, Aplodactylus punctatus, Stellifer minor and Prolatilus jugularis), and 1 was a pelagic species (Thyrsithes atun), together they represented $>89 \%$ of the total number of fishes collected at this locality (Table 1). Of these, $S$. minor and $P$. jugularis were both excluded from the dietary analysis because most specimens captured had empty digestive tracts. The dietary composition of the remaining 6 species consisted of a total of 57 prey items grouped into 23 prey categories (Table 3).

The dietary analysis of the 11 representative species of CE revealed the presence of 3 herbivores, 2 omnivores and 6 carnivores (Table 2). Of the 6 species analyzed at CB, 5 were carnivores and 1 was a herbivore (Table 3 ). Of the 12 species trophically analyzed, 5 were present at both localities. Significant differences in prey composition between both localities were detected through a concordance analysis of Aplodactylus punctatus $\left(\tau_{0.05,9}=\right.$ $0.243, \mathrm{p}=0.179)$; Isacia conceptionis $\left(\tau_{0.05,19}=0.035, \mathrm{p}=0.420\right) ;$ Trachurus murphyi $\left(\tau_{0.05,17}=0.073, \mathrm{p}=0.344\right)$ and Chromis crusma $\left(\tau_{0.05,9}=0.214, \mathrm{p}=\right.$ 0.238 ) of the remaining species, Paralabrax humeralis did not show significant differences in its dietary composition between the 2 localities $\left(\tau_{0.05,20}=\right.$ $0.298, p=0.033)$. At $C E$, green algae (Ulva spp. [50\%] and red algae (Gelidium spp. [10\%] and Chondria spp. [10\%]) were the most important food items in the diet of $A$. punctatus, while at CB brown algae (particularly Lessonia spp. [50\%] and Halopteris spp. [30\%]) were the items most often consumed. Small crustaceans, mostly stomatopods, were the most important prey of $T$. murphyi at CE, while at $\mathrm{CB}$ the diet of this species consisted mainly 
of fishes such as Sardinops sagax (50\%) and Engraulis ringens $(20 \%)$. Copepods and ostracods were the most important prey groups in the diet of Chromis crusma at $\mathrm{CE}$ and $\mathrm{CB}$, respectively. I. conceptionis, the dominant species at both localities, displayed important differences in its dietary composition between localities. At $\mathrm{CE}$, it consumed the green algae Ulva spp. $(30 \%)$ and benthic crustaceans (order Stomatopoda), while at CB it consumed planktonic larvae (megalopa) and gammarid amphipods. This indicates a change in the functional group membership of this species, which is an omnivore at $\mathrm{CE}$, and a carnivore at $\mathrm{CB}$ (see Tables 2 \& 3 for dietary descriptions of $\mathrm{CE}$ and $\mathrm{CB}$, respectively).

\section{Functional groups and feeding guilds}

The analysis and categorization of the functional groups also showed important differences between both localities. The 11 trophically analyzed species present at CE formed 3 functional groups, 1 group consisting of 6 carnivorous species (Cheilodactylus variegatus, Paralabrax humeralis, Labrisomus philippi, Trachurus murphyi, Hemilutjanus macrophthalmos and Chromis crusma), a second group of 3 herbivorous species (Aplodactylus punctatus, Girella laevifrons and Nexilosus latifrons), a third group of 2 omnivorous species (Anisotremus scapularis and Isacia conceptionis), with a possible fourth group comprised of 1 detritivorous species (Mugil cephalus). The majority of the prey species consumed by these different functional groups are benthic species inhabiting the understory algal assemblages common to sites with kelp forests. At $\mathrm{CB}$, the 6 species trophically analyzed formed 2 functional groups; 1 group consisting of 5 carnivorous species (I. conceptionis, P. humeralis, T. murphyi, C. crusma and Thyrsithes atun), and the other of 1 herbivore (Aplodactylus punctatus). In this area, the prey consumed by the carnivores was pelagic (plankton species and ichthyofauna).

The trophic web of the main prey categories (corresponding to more than $90 \%$ of the total biomass of prey items consumed) for these functional groups at both localities is shown in Fig. 3 . There were marked differences be- tween the 2 food webs. At CE, the food web was composed of herbivores, omnivores and carnivores, while at $\mathrm{CB}$ omnivores were absent. At $\mathrm{CE}$, carnivores mostly fed upon benthic prey $(76 \%)$ followed by pelagic prey $(17 \%)$, while at $\mathrm{CB}$, pelagic organisms were the group most heavily preyed-upon by carnivores $(76 \%)$ (Fig. 3). The diet of herbivores at CE was mostly composed of green algae $(75 \%)$, while at $\mathrm{CB}$ brown algae comprised the most important prey item of herbivore fishes ( $84 \%$; Fig. 3).

At $C E$, fishes showed greater species dietary overlap than those co-occurring at $\mathrm{CB}$ (Tables $4 \& 5$ ). The dietary similarity phenogram (Fig. 4) shows that at CE the species can initially be separated into 2 groups: the first comprising 4 species of carnivores, the second 6 species. This second group can be further subdivided into 2 groups, one consisting of 3 herbivores and 1 omnivore and the other of 1 carnivore and 1 omnivore (Fig. 4). Application of the bootstrap technique to determine

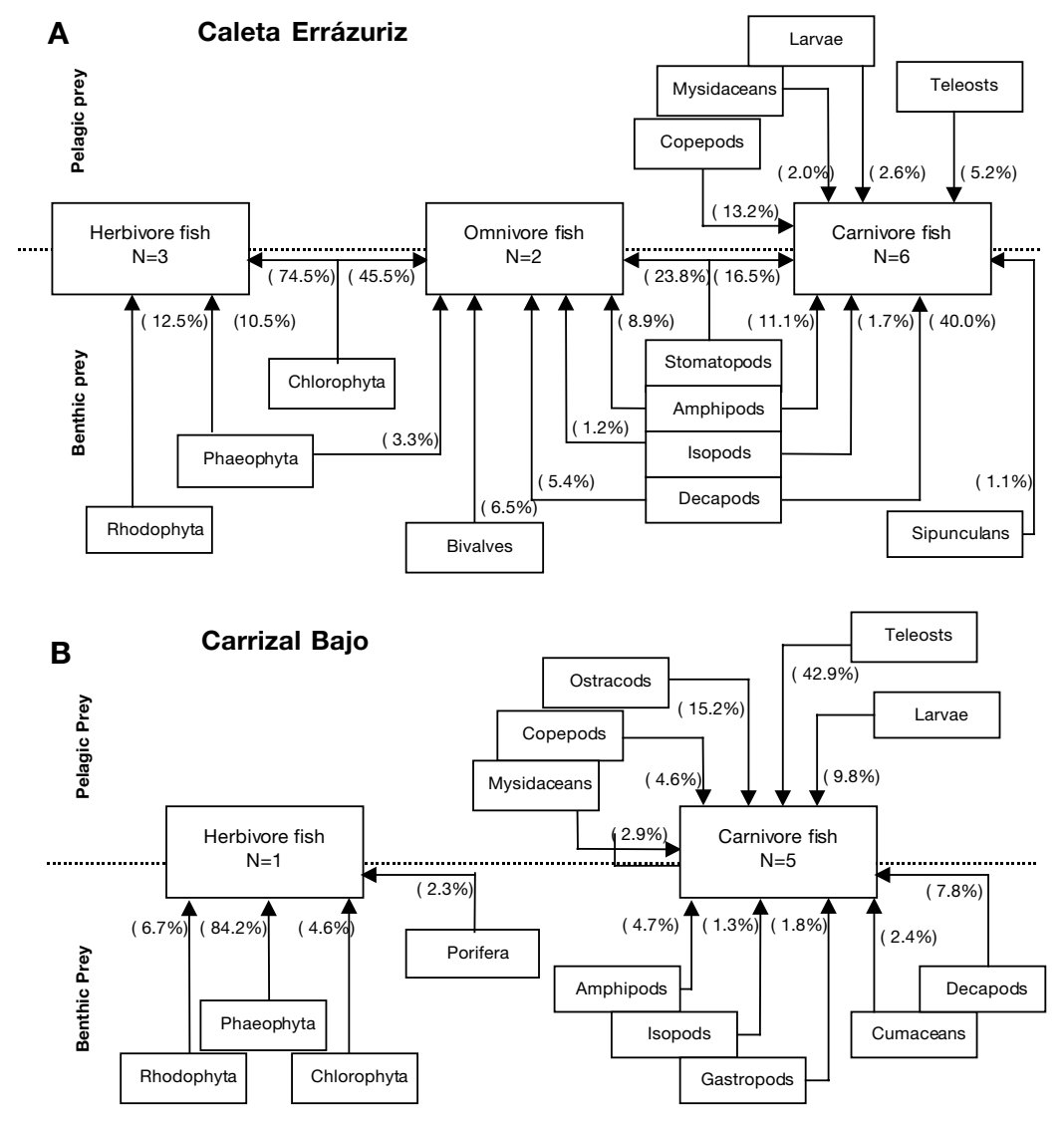

Fig. 3. Trophic web of functional groups of fishes in the subtidal zones of Caleta Errázuriz and Carrizal Bajo. N: number of fishes present in each functional group. Benthic and pelagic prey categories are separated by dotted line. Values in parentheses: percentage of total biomass of each prey category consumed 
Table 4. Dietary overlap among the dominant fish species at Caleta Errázuriz $(\mathrm{N}=11)$ and Carrizal Bajo $(\mathrm{N}=6)$. Overlap between pairs of species calculated using index of Pianka (1973)

\begin{tabular}{|c|c|c|c|c|c|c|c|c|c|c|c|}
\hline Species & As & $A p$ & $C_{V}$ & IC & $P h$ & Gl & $\operatorname{Tm}$ & $H m$ & $L p$ & $N \mathrm{~N}$ & $C_{C}$ \\
\hline Anisotremus scapularis (As) & 1.00 & 0.80 & 0.27 & 0.60 & 0.08 & 0.92 & 0.02 & 0.04 & 0.09 & 0.94 & 0.01 \\
\hline Aplodactylus punctatus (Ap) & & 1.00 & 0.03 & 0.51 & 0.00 & 0.82 & 0.00 & 0.00 & 0.01 & 0.84 & 0.02 \\
\hline Cheilodactylus variegatus $(\mathrm{Cv})$ & & & 1.00 & 0.06 & 0.28 & 0.02 & 0.00 & 0.10 & 0.31 & 0.04 & 0.04 \\
\hline Isacia conceptionis (IC) & & & & 1.00 & 0.03 & 0.59 & 0.78 & 0.29 & 0.03 & 0.61 & 0.02 \\
\hline Paralabrax humeralis $(\mathrm{Ph})$ & & & & & 1.00 & 0.00 & 0.02 & 0.09 & 0.96 & 0.03 & 0.00 \\
\hline Girella laevifrons (GI) & & & & & & 1.00 & 0.00 & 0.00 & 0.01 & 0.95 & 0.00 \\
\hline Trachurus murphyi (Tm) & & & & & & & 1.00 & 0.29 & 0.00 & 0.00 & 0.00 \\
\hline Hemilutjanus macrophthalmos & & & & & & & & 1.00 & 0.18 & 0.00 & 0.00 \\
\hline Labrisomus philippi $(L p)$ & & & & & & & & & 1.00 & 0.04 & 0.00 \\
\hline Nexilosus latifrons (NI) & & & & & & & & & & 1.00 & 0.00 \\
\hline Chromis crusma $\left(C_{C}\right)$ & & & & & & & & & & & 1.00 \\
\hline
\end{tabular}

Table 5. Dietary overlap among the dominant fish species at Carrizal Bajo ( $\mathrm{N}=$ 6). Overlap between pairs of species calculated using index of Pianka (1973)

\begin{tabular}{|lcccccc|}
\hline Species & Ap & IC & Ph & Tm & Ta & Cc \\
\hline Aplodactylus punctatus (Ap) & \multirow{2}{*}{1.00} & 0.04 & 0.03 & 0.00 & 0.00 & 0.00 \\
Isacia conceptionis $($ IC) & & 1.00 & 0.01 & 0.07 & 0.00 & 0.04 \\
Paralabrax humeralis $(P h)$ & & & 1.00 & 0.62 & 0.62 & 0.00 \\
Trachurus murphyi (Tm) & & & & 1.00 & 0.99 & 0.00 \\
Thyrsites atun $(T a)$ & & & & & 1.00 & 0.00 \\
Chromis crusma $(C C)$ & & & & & & 1.00 \\
\end{tabular}

abrax humeralis and Labrisomus philippi). The remaining 5 species (Chromis crusma, Cheilodactylus variegatus, Hemilutjanus macrophthalmos, Isacia conceptionis and Trachurus murphyi) could not be ascribed to any specific trophic guild (Fig. 4). The dietary similarity phenogram of fishes from $\mathrm{CB}$ (Fig. 5) shows that these species can initially be separated into 2 groups, both consisting of 3 species, the first group comprising pelagic carnivores,

guild membership demonstrated that a diet similarity of $>81 \%$ accounted for $>95 \%$ of the artificially generated overlap values obtained by random reshuffling of prey categories. This criterion level indicates the existence of 2 feeding guilds at $\mathrm{CE}$, one consisting of 3 herbivores (Aplodactylus punctatus, Girella laevifrons and Nexilosus latifrons), and 1 omnivore (Anisotremus scapularis) species, and a second of 2 benthic carnivores (Paral- the second group consisting of 2 plankton-consuming carnivores and 1 herbivore species. Application of the bootstrap technique to determine guild membership demonstrated that a dietary similarity of $>60 \%$ accounted for $95 \%$ of the artificially generated overlap values obtained by random reshuffling of prey categories. This criterion level indicates the existence of only 1 feeding guild at $\mathrm{CB}$, consisting of 3 piscivorous

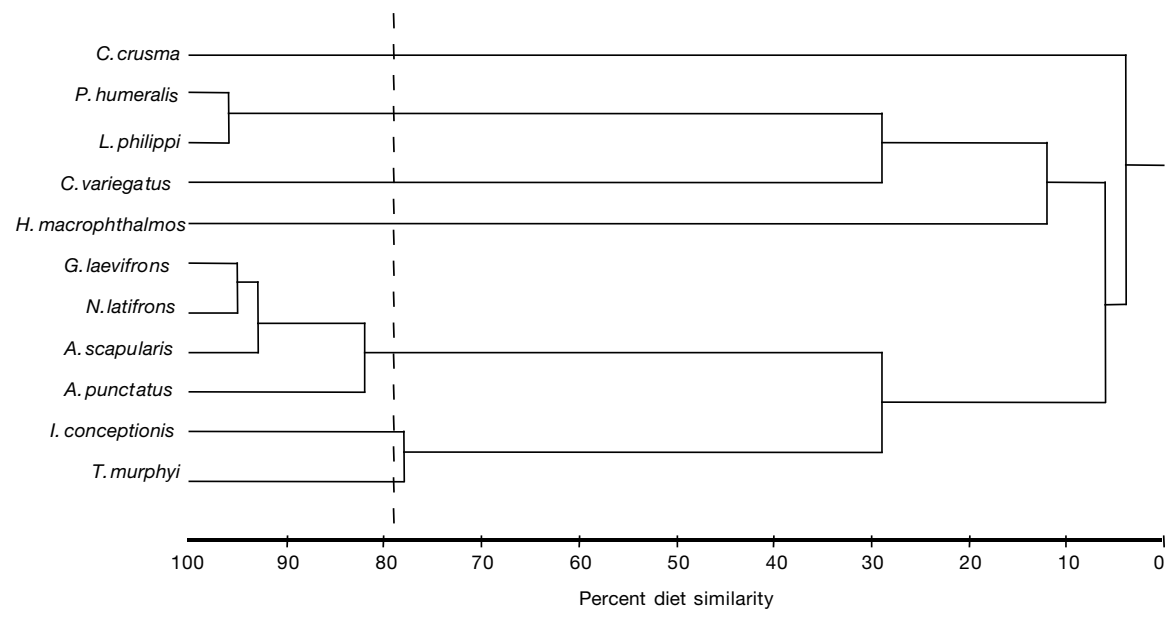

Fig. 4. Diet similarity phenogram of 11 most abundant fish species inhabiting the rocky subtidal of Caleta Errázuriz. Dashed line at $81 \%$ diet similarity indicates 2 feeding guilds significant at $\mathrm{p}<0.05$. full specific names are given in Table 1 
carnivores (Thyrsithes atun, T. murphyi and $P$. humeralis). The remaining 3 species (I. conceptionis, A. punctatus and $C$. crusma) could not be ascribed to any specific trophic guild (Fig. 5).

\section{DISCUSSION}

The present study has shown how habitat complexity influences both the structure and trophic organization of subtidal fish assemblages at 2 localities that differ in spatial structure, CE being the more structurally complex site, CB the structurally simple site. Our results revealed slightly lower species richness at CE (22 species) than at CB (28 species). Thus, contrary to our predictions, a higher species diversity was found at the less structurally complex site. One of the possible reasons for this could be the absence of kelp forest at this site, which leaves both the rocky and sandy bottom open to pelagic species commonly found further offshore. In effect, of the species not found at CE, the majority were large transitory pelagic species.

Also contrary to our expectations, we did not find relative abundance (CPUE) to be significantly higher at the structurally more complex site. However, clear differences were observed in species dominance between both localities. The fish assemblage at $\mathrm{CE}$ was dominated by 4 species, at CB by only 2 , with a lower number of sporadic species at the more complex site. Therefore, it seems that neither species richness nor abundance are primarily important in determining the more complex trophic organization at CE in terms of more functional groups and a more complex guild structure. Possible explanations for this were supplied by the dietary analysis, which showed that, with the exception of Paralabrax humeralis, all species present at both localities displayed differences in the trophic composition of their diet. A clear example of this is given by the most abundant species (Isacia conceptionis) at both localities. This species has an omnivorous benthic feeding habit at $\mathrm{CE}$ and a carnivorous pelagic feeding habit at CB. These differences not only indicate trophic plasticity of the species, but also possible responses to differences in prey availability at each locality. Evidence of this has been provided by Vásquez et al. (1998), who found that the subtidal benthic substrate at CE presents a greater invertebrate species richness and total algal biomass, compared to that at CB. Furthermore, CE is dominated by green and brown algae, while green algae are practically absent from CB (Cáceres et al. 1994, Vásquez et al. 1998). In a trophic ecology study of the herbivore Aplo- dactylus punctatus, Cáceres et al. (1994) found Ulva sp. to be the most consumed food item in CE, underlining the higher energetic value and digestibility of this alga in comparison to the more abundant brown alga Lessonia sp. At CB, the lower abundance of green algae documented by Vásquez et al. could be the reason for the dietary shift observed in A. punctatus in the present study. Cáceres et al. (1994) found similar results in central Chile, where the availability of green algae is low, and the diet of A. puctatus was mainly composed of the brown alga Lessonia sp.

Analysis of the assemblage as a whole, in terms of functional groups at each locality, revealed the generality of these shifts in trophic behavior. There was a greater diversity of functional groups at the more complex site (CE) than at the structurally simple site (CB), and although carnivores represented the most important functional group at both localities, the prey items consumed by the species differed between the various functional groups. The trophic web structure at the 2 sites shows how in the presence of a kelp forest both carnivores and omnivores consume mainly benthic prey that occur in the understory canopy, while in the absence of a kelp forest the carnivores feed on pelagic prey present in the water column. Similar results were documented by Love \& Ebeling (1978) at 2 sites off Santa Barbara, California, where in the absence of kelp forest the fish species switched from large benthic prey, typical of kelp sites, to plankton. On the other hand, the herbivores fed mainly on green algae at CE and brown algae at $\mathrm{CB}$. The differences in the number of functional groups as well as the types of prey consumed at each locality could be related to 2 important factors differentiating these localities: the presence of a kelp forest at CE compared to scattered kelp stands at CB, and differences in the availability of nutrients (productivity) (Vásquez et al. 1998, Camus \& Andrade 1999), which, in turn, affect the availability of prey at each locality. Indeed, increased levels of productivity related to coastal 
upwelling have been documented for CE (Bosman et al. 1987, Fonseca \& Farías 1987, Marin et al. 1993, Vásquez et al. 1998) as opposed to CB, where there is no upwelling. Camus \& Andrade (1999) proposed that the greater biomass of Ulva spp. at CE could be due to the capability of this species to respond to high values of nutrient availability, thus reflecting the preference for this item by herbivores at this locality.

These differences are further reflected in the trophic web structure at each locality. At $\mathrm{CE}$, the trophic web is not only more complex in terms of number of species and interactions, but also the 3 functional fish groups are much more interconnected by way of sharing a number of prey species (Fig. 3A). In contrast, at CB, the trophic web is not only more simple in terms of fish diversity and interacting prey species, but also the absence of omnivorous fishes results in 2 disconnected sub-webs (Fig. 3B). These differences in trophic web structure probably reflect the effect of an increased environmental complexity generated by the kelp forest at CE. It is well known that kelp forests not only provide more opportunities for microhabitat utilization by reef fishes, but also determine high levels of prey availability, particularly to species inhabiting the kelp understory (Choat \& Ayling 1987).

On the other hand, the more complex guild structure of the assemblage at the kelp forest site reflects not only what resources are being used and by what species, but also the possible identity and sign of the ecological relations between these species. The presence of species guilds in communities has been widely discussed as a possible strategy for avoiding trophic competition (Pianka 1980) or (in the case of discontinuities along a resource axis) as a means of optimizing available resources (Jaksic 1981). At the more complex site, 6 fish species were grouped into 2 feeding guilds, one consisting of herbivorous species, all of which consumed the green macroalgae Ulva spp. as the main prey item, and the other composed of 2 carnivorous species that fed mainly on decapod crabs. At the structurally simpler site, 3 carnivorous species grouped into 1 guild and the main prey item were fishes. Thus, at the more complex site, algal prey items such as Ulva spp. and decapod crabs could be responsible for a greater degree of interaction among species than the smaller crustacean species consumed by the rest of the fish species analyzed. At the simpler site, fish prey could be responsible for a greater degree of interaction between the species present as opposed to the plankton consumed by the rest of the fish species analyzed. However, as MacNally (1983) pointed out, both the occurrence and the degree of interaction among species should be investigated in manipulative experiments, rather than assuming that because species share the same resources they should compete (Root 1967).

\section{CONCLUSION}

The trophic characterization of the fish assemblages in 2 localities that differed in habitat structure allowed us to determine both the structure and organization of these assemblages. At $\mathrm{CE}$, the more complex habitat structure, the presence of large kelp forests provides not only more refuge but also direct and indirect sources of food. This, in addition to a greater cover of rocky substratum and nutrient availability in the water column, could be responsible for the greater algal and invertebrate biomass present at this locality and account for its greater species dominance as well as the more complex trophic structure and organization of the fish assemblage in terms of functional groups and guilds. However, in contrast to previous studies of kelp sites, we did not find greater diversity or abundance. In New Zealand, Choat \& Ayling (1987) found that in areas of low bottom-relief greater total fish densities were much higher in kelp beds than in urchin barrens. Similarly, Levin \& Hay (1996) in North Carolina addressed the question of how variance in algal structure of smaller seaweeds such as Sargassum filipendula affects reef fish abundance and distribution, and found that both the presence and higher density of this alga increased fish density and diversity of small-sized fish. In our study we also found smaller sized fish within the kelp-dominated site, perhaps an indication that both kelp beds and smaller-sized algal stands provide critical habitat for settlement and early development of larvae (Holbrook et al. 1990, Anderson 1994, Levin \& Hay 1996). At CB, the less complex habitat structure and poorer nutrient availability determine the more simplified structure and organization of the fish assemblage present. Analysis of functional groups and guilds allowed the fish assemblages to be compared on equal terms, stressing similarities among unrelated species and making it possible to compare them across different spatial regions. This study serves thus as a necessary step towards a further unravelling of the possible mechanisms and processes involved in the structuring and organization of subtidal fish assemblages.

Acknowledgements. We thank J. M. Rojas, P. Pulgar and F. Ogalde for their help in the field, P. López for her assistance in the dietary analysis, and F. Labra for his suggestions and help with the data analysis. J. M. Fariña, A. A. Muñóz and A. Palma and 3 anonymous referees provided valuable advice which improved the overall quality of this paper. This research was supported by FONDECYT grant 5960001 and FONDAP O \& MB (No. 3) while writing.

\section{LITERATURE CITED}

Anderson TW (1994) Role of macroalgal structure in the distribution and abundance of a temperate reef fish. Mar Ecol Prog Ser 113:279-290 
Bodkin JL (1988) Effects of kelp removal on associated fish assemblages in central California. J Exp Mar Biol Ecol 117:227-238

Bosman AL, Hockey PA, Siegfried WR (1987) The influence of coastal upwelling on the functional structure of rocky intertidal communities. Oecologia 72:226-232

Cáceres CW, Fuentes LS, Ojeda FP (1994) Optimal feeding strategy of the temperate herbivorous fish Aplodactylus punctatus: the affects of food availability on digestive and reproductive patterns. Oecologia 99:118-123

Camus PA, Andrade YN (1999) Diversidad de comunidades intermareales rocosas del norte de Chile y el efecto potencial de la surgencia costera. Rev Chil Hist Nat 72: $389-410$

Camus PA, Ojeda FP (1992) Scale-dependent variability of density estimates and morphometric relationships in subtidal stands of the kelp Lessonia trabeculata in northern and central Chile. Mar Ecol Prog Ser 90:193-200

Carr MH (1991) Habitat selection and recruitment of an assemblage of temperate zone reef fishes. J Exp Mar Biol Ecol 146:113-137

Colwell RK (1997) Estimate S. Statistical estimation of species richness and shared species from samples. Version 5.0.1. Univ of Connecticut

Choat JH, Ayling AM (1987) The relationship between habitat structure and fish faunas on New Zealand reefs. J Exp Mar Biol Ecol 110:257-284

Choat JH, Schiel DR (1982) Patterns of distribution and abundance of large brown-algae and invertebrate herbivores in subtidal regions of northern New Zealand. J Exp Mar Biol Ecol 60:29-162

Dayton PK (1985) Ecology of kelp communities. Annu Rev Ecol Syst 16:215-245

DeMartini EE, Roberts DA (1990) Effects of giant kelp (Macrocystis) on the density and abundance of fishes in a cobble-bottom kelp forest. Bull Mar Sci 46:287-300

Ebeling AW, Hixon MA (1991) Tropical and temperate reef fishes: comparison of community structures. In: Sale PF (ed) The ecology of fishes on coral reefs. Academic Press, San Diego, p 509-561

Ebeling AW, Larson RJ, Alevizon WS, Bray RN (1980) Annual variability of reef-fish assemblages in kelp forests off Santa Barbara, California. Fish Bull US 78:361-377

Fonseca TR, Farías M (1987) Estudios de los procesos de surgencia en la costa Chilena utilizando percepción remota. Invest Pesq (Chile) 34:33-46

Holbrook SJ, Carr MH, Schmitt RJ, Coyer JA (1990) Effect of giant kelp on local abundance of reef fishes: the importance of ontogenetic resource requirements. Bull Mar Sci 47:104-114

Jaksic FM (1981) Abuse and misuse of the term 'guild' in ecological studies. Oikos 37:397-400

Jaksic FM, Medel R (1990) Objective recognition of guilds: testing for statistically significant species clusters. Oecologia 83:87-92

Jaramillo E, Carrasco F, Quijon P, Pino M, Contreras H (1998) Distribución y estructura comunitaria de la macroinfauna bentónica en la costa norte de Chile. Rev Chil Hist Nat 71: 459-478

Lawlor LR (1980) Structure and stability in natural and randomly constructed competitive communities. Am Nat 116: 394-408

Levin PS, Hay M (1996) Responses of temperate reef fishes to alterations in algal structure and species composition. Mar Ecol Prog Ser 134:37-47

Love MS, Ebeling AW (1978) Food and habitat of three switch-feeding fishes in the kelp forest off Santa Barbara, California. Fish Bull US 76:257-271

MacNally RC (1983) On assessing the significance of interspecific competition to guild structure. Ecology 64: $1646-1652$

Marin V, Rodriguez L, Vallejo L, Fuenteseca J, Oyarce E (1993) Efectos de la surgencia costera sobre la productividad primaveral de Bahía Mejillones del sur (Antofagasta, Chile). Rev Chil Hist Nat 66:479-491

Miranda O (1967) Calendario ictiológico de San Antonio 1. Biol Pesq 2:3-49

Moreno CA, Jara HF (1984) Ecological studies of fish fauna associated with Macrocystis pyrifera belts in the south of Fueguian Islands, Chile. Mar Ecol Prog Ser 15:99-107

Moreno CA, Duarte WE, Zamorano JH (1979) Varianción latitudinal del número de especies de peces sublitoral rocoso: una explicación ecológica. Arch Biol Med Exp 12: $169-178$

Muñoz AA, Ojeda PF (1997) Feeding guild structure of a rocky intertidal fish assemblage in central Chile. Environ Biol Fish 49:471-479

Nuñez LM, Vasquez JA (1987) Observaciones tróficas y de distribución especial de peces asociados a un bosque submareal de Lessonia trabeculata. Estudios Oceanol (Chile) 6:79-85

Pianka ER (1973) The structure of lizard communities. Annu Rev Ecol Syst 4:53-74

Pianka ER (1980) Guild structure in desert lizards. Oikos 35: $194-201$

Quast JC (1968) Fish fauna of the rocky inshore zone. In: North WJ, Hubbs CL (eds) Utilization of kelp bed resources in southern California. Calif Dep Fish Game Fish Bull 139:57-79

Root RB (1967) The niche exploitation pattern of the blue-gray gnatcatcher. Ecol Monogr 37:317-350

Schiel DR, Foster MS (1986) The structure of subtidal algal stands in temperate waters. Oceanogr Mar Biol Annu Rev 24:265-307

Siegel S, Castellan NJ (1988) Nonparametric statistics for behavioral sciences. McGraw Hill, New York

Steele MA (1999) Effects of shelter and predators on reef fishes. J Exp Mar Biol Ecol 233:65-79

Stephens JS Jr, Morris PA, Zerba K, Love M (1984) Factors affecting fish diversity on a temperate reef: the fish assemblage of Palos Verdes point 1974-1981. Environ Biol Fish 11:259-275

Tegner MJ, Dayton PK (1987) El Niño effects on southern California kelp forest communities. Adv Ecol Res 17:243-279

Vargas ME, Soto RA, Guzmán GL (1999) Cambios interanuales en la alimentación de peces submareales del norte de Chile entre los $20^{\circ} 11^{\prime} \mathrm{S}$ y $20^{\circ} 20^{\prime} \mathrm{S}$. Rev Biol Mar Oceanogr 32:197-210

Vásquez AJ, Camus PA, Ojeda FP (1998) Diversidad, estructura y funcionamiento de ecosistemas costeros rocosos del norte de Chile. Rev Chil Hist Nat 71:479-499

Wharton WG, Mann KH (1981) Relationships between destructive grazing by the sea urchin Strongylocentrus droebachienisi, and the abundance of the American lobster Homarus americanus on the Atlantic coast of Nova Scotia. Can J Fish Aquat Sci 83:1339-1349

Submitted: July 12, 1999; Accepted: December 8, 2000

Proofs received from author(s): July 3, 2001 